\title{
The significance of interleukin 8 in urine
}

\author{
W H Rao, G S Evans, A Finn
}

\begin{abstract}
Aims-To assess the implications of detection of interleukin 8 (IL-8) in urine. Methods-IL-8 was measured by immunoassay in all 305 urine samples from children aged $0-18.4$ years received by our microbiology laboratory during four weeks, with a retrospective structured case note audit for all those in whom IL-8, white cells, or bacteria were detected. Patients were divided into three groups: urinary tract infection (UTI), at least one sample with $\geqslant 5$ leucocytes $\times 10^{9} / 1$ and $\geqslant 10^{5}$ cultured bacteria/ml; possible UTI, at least one sample with $\geqslant 5$ leucocytes $\times 10^{9} / 1$ or $\geqslant 10^{5}$ cultured bacteria/ml but not both; UTI unlikely, sample(s) with $<5$ leucocytes $\times 10^{9} / 1$ and $<10^{5}$ cultured bacteria/ml. Medical records were sought for all in groups 1 (14/14 found) and 2 (18/21 found) and those in group 3 (41/59 found) in whose urine any leucocytes, cultured bacteria, or IL-8 were detected.

Results-IL-8 was detected in 58/305 samples from $48 / 264$ patients. IL-8 was detected in at least one urine sample from 13/14 patients with confirmed UTI (group 1 ); in 11/21 patients with possible UTI (group 2), of whom two were treated as UTI; and in $23 / 228$ patients without UTI. Using a cut off of $200 \mathrm{pg} / \mathrm{ml}$, urine IL-8 had a sensitivity of $93 \%$ and a specificity of $\mathbf{9 0 \%}$ for diagnosing UTI.

Conclusions-Urine IL-8 is a sensitive test for UTI, but is poorly specific as it is also present in a variety of other infectious and inflammatory disorders.

(Arch Dis Child 2001;85:256-262)
\end{abstract}

Keywords: urinary tract infection; interleukin 8 ; diagnostic tests

The diagnosis of urinary tract infection (UTI) relies heavily on microbiological examination of urine and, in particular, demonstration of the presence of leucocytes and bacteria. Interpretation of these findings is controversial and is rendered more difficult in childhood by practical difficulties in obtaining uncontaminated urine to order, and by lack of alternative diagnostic approaches. Significant numbers of children may receive unnecessary treatment, and, more seriously, some may not be treated or have necessary treatment delayed, potentially resulting in permanent structural and functional damage to kidneys and ureters or other serious morbidity. ${ }^{1}$

Interleukin 8 (IL-8) can be produced by epithelial cells of the renal tract in response to a variety of inflammatory stimuli. ${ }^{2}$ The cytokine has been shown in inflamed renal tissue in patients with acute allograft rejection, ${ }^{2}$ and high serum concentrations have been reported in patients with renal failure. ${ }^{3}$ IL- 8 has been reported in the urine of patients with several inflammatory renal disorders including pyelonephritis, ${ }^{4}$ haemolytic uraemic syndrome, ${ }^{5}$ graft rejection following renal transplantation, ${ }^{67}$ and various forms of glomerulonephritis. ${ }^{8}$ IL-8 is found in the urine of patients with urinary tract infection, ${ }^{9}$ including neonates ${ }^{10}$; recent studies suggest a direct association between urine IL- 8 concentrations and clinical severity in paediatric urinary tract infection $^{11}$ and in urinary tract infection following renal transplantation in adults. ${ }^{7} \mathrm{We}$ have assessed the clinical significance IL- 8 in urine of children in clinical practice in a children's hospital.

\section{Materials and methods}

URINE SAMPLES

Residual urine from consecutive samples received by our microbiology laboratory from paediatric patients for microscopy and culture was collected over a four week period. The use of such samples, otherwise to be discarded, was approved by the local ethics committee. Samples were centrifuged at $1200 \mathrm{~g}$ for 15 minutes at $4^{\circ} \mathrm{C}$ and the supernatant was collected and stored at $-70^{\circ} \mathrm{C}$ until analysis. A total of 306 samples were collected from 264 patients aged between $<0.1$ and 18.4 years (although in several cases the date of birth and thus age was not established). One sample was insufficient for analysis, thus 305 samples, from 264 patients, were assayed for IL-8.

\section{IMMUNOASSAY}

An in house sandwich enzyme linked immunosorbent assay (ELISA) for IL-8 was used, as described previously, ${ }^{12}$ to determine IL-8 concentrations in the urine samples. A monoclonal anti-IL-8 capture antibody (TY1, HB 9647, a gift of E J Leonard) and a polyclonal sheep antihuman IL8 detection serum (a gift of A Mire-Sluis, NIBSC) conjugated to biotin (Pierce \& Warriner, Chester, UK) were used. The assay was shown to be specific for IL-8 in urine using competition assays with IL- 8 and other recombinant cytokines (data not shown). In order to circumvent a $\mathrm{pH}$ dependent change in assay performance using the TY antibody, a 2-[N-morpholino] ethanesulphonic acid (MES) buffer was used $1 / 1$ with urine. This buffer has maximal buffering capacity in the $\mathrm{pH}$ range 5.5-6.7 at which assay performance is optimal. All samples were run in duplicate, and concentrations were determined from standard curves generated from dilutions of recombinant human IL-8. The lower detection 
Table 1 Details of samples from patients designated UTI (group 1)

\begin{tabular}{|c|c|c|c|c|c|c|c|}
\hline Age (y) & Timing of samples & WCC $\left(\times 10^{9} / l\right)$ & $\log _{10}($ org ct $) / m l$ & $\begin{array}{l}I L-8 \\
(p g / m l)\end{array}$ & Culture report & Acute conditions & Chronic conditions \\
\hline 0.7 & - & 15 & 6 & 5816 & $\begin{array}{l}\text { Mixed growth including } \\
\text { coag neg staph } \\
\text { predominantly }\end{array}$ & PUO; pneumonia & - \\
\hline \multirow[t]{2}{*}{1.1} & Sm1 & $>100$ & 6 & 4926 & E coli & \multirow{2}{*}{$\begin{array}{l}\text { UTI; UT surgery (L } \\
\text { ureterostomy; R } \\
\text { ureterostomy) }\end{array}$} & \multirow{2}{*}{$\begin{array}{l}\text { Bilateral hydronephrosis } \\
\text { and hydroureters; } \\
\text { recurrent UTI }\end{array}$} \\
\hline & Sm $1+3$ days & $4-5$ & 6 & 3110 & Multiple organisms & & \\
\hline 3.9 & - & $>100$ & 8 & 3610 & Citrobacter diversus & Routine sample & $\begin{array}{l}\text { Incontinence; recurrent } \\
\text { UTI }\end{array}$ \\
\hline 10.9 & - & $>100$ & 6 & 2474 & E coli & UTI & $\begin{array}{l}\text { Anorectal anomaly and } \\
\text { neurogenic bladder; } \\
\text { ureteric reflux; recurrent } \\
\text { UTI }\end{array}$ \\
\hline${ }^{\star} 0.7$ & Sm1 & 30 & 7 & 1856 & Coliform & UTI; PUO & - \\
\hline 9.1 & - & 100 & $>5$ & 1766 & Coliform & UTI & - \\
\hline \multirow[t]{3}{*}{1.7} & Sm1 & $10-15$ & 5 & 0 & E coli & \multirow[t]{3}{*}{ PUO } & \multirow{3}{*}{$\begin{array}{l}\text { Recurrent UTI; Down's; } \\
\text { epilepsy }\end{array}$} \\
\hline & Sm $1+5$ days & 10 & 8 & 0 & E coli & & \\
\hline & Sm $1+6$ days & 8 & 7 & 1326 & & & \\
\hline N/A & - & $30-35$ & 6 & 1010 & Coliform & UTI & - \\
\hline 2.8 & - & 30 & 6 & 668 & Pure growth $E$ coli & UTI & $\begin{array}{l}\text { Recurrent UTI; } \\
\text { constipation }\end{array}$ \\
\hline †0.9 & Sm $1+6$ days & 25 & 8 & 480 & Coliform & UTI; PUO & Biliary atresia \\
\hline 3.1 & - & $20-25$ & 7 & 440 & E coli & PUO & - \\
\hline$\ddagger 10.1$ & - & 20 & 8 & 430 & Mixed growth & PUO & Constipation \\
\hline 0.6 & - & 40 & $>5$ & 0 & Pure growth $E$ coli & $\begin{array}{l}\text { Rotavirus } \\
\text { gastroenteritis; UTI }\end{array}$ & $\begin{array}{l}\text { Ureteric reflux shown } \\
\text { subsequently }\end{array}$ \\
\hline$\$ 0.2$ & Sm $1+1$ day & $25-30$ & 8 & 0 & Coliform & $\begin{array}{l}\text { Choking episode; } \\
\text { diarrhoea and vomiting }\end{array}$ & $\begin{array}{l}\text { Gastro-oesophageal } \\
\text { reflux }\end{array}$ \\
\hline
\end{tabular}

${ }^{\star}+\neq$ SIndicate corresponding patients in tables 1 and 2 .

UTI, urinary tract infection; PUO, pyrexia of unknown origin; N/A, information not available; WCC, white cell count; org ct, organism count; L, left; R, right; coag neg staph, coagulase negative staphylococcus; Sm, sample; neg, negative.

limit of the assay was $200 \mathrm{pg} / \mathrm{ml}$, and the intraassay and interassay coefficients of variation were $2.94 \%$ and $8.69 \%$, respectively.

PATIENT RECORDS

Patients were divided into three groups for analysis according to the presence of white blood cells, organisms, and IL-8 in the urine samples. Patients whose urine contained white blood cells $\geqslant 5 \times 10^{9} / 1$ and a pure or mixed culture of bacteria $\geqslant 10^{5}$ colony forming units $(\mathrm{CFU}) / \mathrm{ml}$ were designated UTI (group 1, table 1 ). When a patient had one or more samples designated to group 1 , any other samples from that patient which did not fulfil the study definition for UTI were listed in table 2. Patients whose urine contained either white blood cells $\geqslant 5 \times 10^{9} / 1$ or a pure or mixed urine culture of bacteria $\geqslant 10^{5} \mathrm{CFU} / \mathrm{ml}$ but not both, were designated possible UTI (group 2, table 3). All the remaining patients, whose urine contained white blood cells $<5 \times 10^{9} / 1$ or no white blood cells but a culture of bacteria $<10^{5} \mathrm{CFU} / \mathrm{ml}$ or sterile urine were designated unlikely to have UTI (group 3). In order to ascertain the concordance of these designations with the conclusions reached by the managing clinicians at the time and to obtain further descriptive clinical information about these groups, we

Table 2 Details of additional samples that did not fulfil the study definition for UTI from patients designated UTI (group 1)

\begin{tabular}{llllll}
\hline Age $(y)$ & Timing & $W C C\left(\times 10^{9} / l\right)$ & $\log _{10}($ org $c t) / m l$ & $\begin{array}{l}I L-8 \\
(p g / m l)\end{array}$ & Culture report \\
\hline$\star_{0.7}$ & Sm1+4 days & $2-5$ & 6 & 922 & $\begin{array}{l}\text { Mixed } \\
\text { contaminants }\end{array}$ \\
& & & & Neg \\
$\dagger 0.9$ & Sm 1 & 0 & $<3$ & 896 & Neg \\
$\$ 0.2$ & Sm 1 & 0 & 0 & 692 & Neg \\
$\ddagger 10.1$ & Sm1+1 day & 15 & 0 & 0 & \\
\hline
\end{tabular}

$\star+\ddagger \oint$ Indicate corresponding patients in tables 1 and 2 .

UTI, urinary tract infection; WCC, white cell count; org ct, organism count; Sm, sample; neg, negative. sought the medical records of all patients in group 1 and group 2 and all those in group 3 in whose urine we found any white blood cells, any bacteria by culture, or any IL- 8 above the lower limit of detection $(200 \mathrm{pg} / \mathrm{ml})$. Table 4 presents data from cases in group 3. We assumed, without checking the medical records, that children whose urine was free from all three markers on all tests did not have UTI. Each set of records was interrogated by a single clinician using a standard questionnaire; the following data were extracted:

- Presence or absence of the following chronic conditions: abnormal urethra, ectopic bladder, neuropathic bladder, horseshoe kidney, chronic catheter placement, ureteric reflux, renal scarring, recurrent UTI, hydronephrosis, incontinence, constipation, spina bifida, rickets, anaemia. Other underlying chronic conditions were noted.

- Presence or absence of the following acute conditions or reasons for urine sampling: clinical diagnosis of suspected UTI, recent urinary tract surgery (including ureterostomy), upper respiratory infection, investigation for pyrexia of unknown origin, or for diarrhoea and vomiting, pneumonia, appendicitis, pancreatitis, and vaginitis.

\section{Results}

IL-8 was detected in 58/305 samples from $48 / 264$ patients. However, six of these samples, all containing $>8 \mathrm{ng} / \mathrm{ml}$ IL- 8 , were grossly bloody, having been taken shortly after urinary tract surgery from three patients, so were excluded from further analysis. Subsequent samples from these patients were included (two in group 2, one in group 3, taken 6, 2, and 11 days postsurgery, respectively, and containing 
Table 3 Details of samples from patients designated possible UTI (group 2)

\begin{tabular}{|c|c|c|c|c|c|c|}
\hline Age (y) & $W C C\left(\times 10^{9} / l\right)$ & $\log _{10}($ org ct $) / m l$ & $I L-8(p g / m l)$ & Culture report & Acute conditions & Chronic conditions \\
\hline \multirow[t]{2}{*}{1.0} & $10-15$ & 0 & 8334 & $\mathrm{Neg}$ & Recent UT surgery & Horseshoe kidney; hydronephrosis; \\
\hline & $1-2$ & 0 & 0 & & (samples from stent) & recurrent UTI; ureteric reflux \\
\hline 5.4 & 10 & $<3$ & 5022 & Neg & UTI & Abnormal urethra \\
\hline 13.5 & 0 & 6 & 2700 & Coliform & & $\begin{array}{l}\text { Abnormal urethra; recurrent UTI; } \\
\text { chronic catheter }\end{array}$ \\
\hline N/A & $1-2$ & 5 & 858 & E coli & UTI & \\
\hline 0.5 & 6 & $<3$ & 858 & Coliforms $\times 3$ & PUO & \\
\hline 7.5 & 5 & 4 & 814 & $\begin{array}{l}\text { Coliform and coag neg } \\
\text { staph }\end{array}$ & Routine sample & Incontinence \\
\hline 12.8 & 10 & 0 & 750 & Neg & $\begin{array}{l}\text { Recent UT surgery } \\
\text { (sample from stent) }\end{array}$ & $\begin{array}{l}\text { Ureteric reflux; incontinence; recurrent } \\
\text { UTI }\end{array}$ \\
\hline 5.6 & 50 & 0 & 456 & Neg & Routine sample & Recurrent UTI \\
\hline 7.6 & 8 & 0 & 456 & Neg & & Vaginitis \\
\hline 7.5 & $35-40$ & 0 & 412 & Neg & & Urinary catheter; spina bifida \\
\hline 3.6 & 10 & 4 & 404 & E coli & Routine sample & $\begin{array}{l}\text { Spina bifida with hyperdynamic } \\
\text { bladder, incontinence, ureteric reflux }\end{array}$ \\
\hline 10.8 & 50 & 0 & 0 & Neg & & Constipation \\
\hline 13.0 & 20 & 0 & 0 & Neg & $\begin{array}{l}\text { Abdominal pain and } \\
\text { vomiting }\end{array}$ & Constipation \\
\hline 6.4 & 20 & 0 & 0 & Neg & PUO & \\
\hline N/A & 10 & 0 & 0 & Neg & URI & \\
\hline 7.4 & 5 & 0 & 0 & Neg & URI & \\
\hline 10.7 & 5 & 0 & 0 & Neg & Routine sample & $\begin{array}{l}\text { Ureteric reflux; abnormal bladder; } \\
\text { constipation; recurrent UTI }\end{array}$ \\
\hline 2.9 & 5 & 0 & 0 & Neg & URI & \\
\hline 2.0 & 0 & 6 & 0 & Coliform & & No clinical information \\
\hline 1.2 & 0 & 5 & 0 & $\begin{array}{l}\text { Coliforms and coag } \\
\text { neg staph }\end{array}$ & & No clinical information \\
\hline N/A & 5 & 0 & 0 & $\mathrm{Neg}$ & & No clinical information \\
\hline
\end{tabular}

UT, urinary tract; UTI, urinary tract infection; URI, upper respiratory infection; PUO, pyrexia of unknown origin; N/A, information not available; WCC, white cell count; org ct, organism count; coag neg staph, coagulase negative staphylococcus; Sm, sample; Neg, negative.

$1-2,10$, and 2 red cells, but no sample from these patients was culture positive). In the remaining 52 samples, IL-8 concentrations were: mean $1539.4 \mathrm{pg} / \mathrm{ml}$, median $922 \mathrm{pg} / \mathrm{ml}$, range $404-8334 \mathrm{pg} / \mathrm{ml}$.

The medical records were sought for a total of 97 children, 14 in group 1, 21 in group 2, and 59/228 in group 3 . Of these, all 14, 18, and 41 respectively were located and examined. The remaining 21 were excluded from analysis of clinical features and, in the case of those 18 from group 3 whose records were not found, also excluded from analysis of the diagnostic value of IL-8 in urine (see below).

GROUP 1

Fourteen patients were designated "urinary tract infection"(UTI) using the criteria described above (group 1). Seventeen of the 21 samples obtained from these 14 patients fulfilled the study definition for UTI (table 1). Four samples did not (table 2). IL-8 was detected in 16 of the 21 urine samples. All but one of these patients had at least one sample with detectable IL-8. In one patient a sample containing detectable IL-8 (692 pg/ml) contained no bacteria or white cells. A further sample obtained the following day contained $25-30$ white cells and cultured $10^{8}$ bacteria $/ \mathrm{ml}$, but contained no detectable IL-8. Three other samples contained white cells and bacteria sufficient to meet the study definition of UTI but no IL-8. One was in the single sample from the only patient in this group in whom IL-8 was not detected. This child had a further sample taken seven days later that also showed pyuria and from which Escherichia coli was cultured, confirming UTI. The second sample was outside the study collection period and was not assayed for IL-8. The remaining two samples were the first two from a series of three samples obtained from a child with Down's syndrome and a history of recurrent UTI. All three samples of the series fulfilled the study definition for UTI but only the third contained detectable IL-8. Two other samples that did not fulfil the study definition of UTI from patients in this group (table 2) cultured bacteria and one also showed 2-5 white cells $\times 10^{9} / 1$. Both samples contained detectable IL-8. Both patients had other samples that did fulfil the UTI definition and also contained detectable IL-8.

A final sample that did not fulfil the study definition of UTI (table 2) contained 15 white cells $\times 10^{9} / 1$ but was sterile and contained no detectable IL-8. It was taken from a 10 year old patient the day after a sample fully diagnostic of UTI and containing IL-8.

The mean, median, and range values for the 17 samples fulfilling the criteria for UTI were $1642 \mathrm{pg} / \mathrm{ml}, 1010 \mathrm{pg} / \mathrm{ml}$, and $0-5816 \mathrm{pg} / \mathrm{ml}$.

As expected, around half of this group were aged less than 2 years at the time of UTI and the infections were, for the most part, caused by $E$ coli or other coliforms.

Figure 1 shows the relation between urine IL-8 concentrations and white cell count in the samples in the group. As expected there is a broad correlation $(r=0.44, \mathrm{p}<0.001)$.

\section{GROUP 2}

Twenty one patients (21 samples) were designated "possible urinary tract infection" using the criteria described above (group 2). Of these, clinical data were obtained in 18 cases (table 3). IL-8 was detected in 11 of the 21 urine samples. Of these 11 , eight were from children with some form of chronic urinary tract pathology or recurrent urinary tract disease. Urinary tract infection was either primarily suspected or being screened for in all these 11 cases; in two, despite the equivocal results, the children were judged to have UTI and treated. In only one case was a non-urinary 
Table 4 Details of samples from patients who were not designated UTI (group 3)

\begin{tabular}{|c|c|c|c|c|c|c|c|}
\hline $\operatorname{Age}(y)$ & $\begin{array}{l}\text { Timing of } \\
\text { samples }\end{array}$ & $\begin{array}{l}W C C(\times \\
\left.10^{9} / l\right)\end{array}$ & $\log _{10}($ org ct $) / m l$ & $\begin{array}{l}I L-8 \\
(p g / m l)\end{array}$ & Culture report & Acute conditions & Chronic conditions \\
\hline 12.3 & & 0 & 0 & 3960 & Neg & Pancreatitis & Recurrent pancreatitis \\
\hline 9.9 & & 0 & $<3$ & 3142 & $\begin{array}{l}\text { "Mixed } \\
\text { contaminants" }\end{array}$ & Routine sample & $\begin{array}{l}\text { Ureteric reflux and renal scarring; } \\
\text { recurrent UTI; resection duplex } \\
\text { kidney }\end{array}$ \\
\hline 3.9 & & $<1$ & 0 & 2438 & $\begin{array}{l}8 \text { perioperative } \\
\text { samples all negative }\end{array}$ & $\begin{array}{l}\text { Recent UT surgery (sample } \\
\text { from ureteric stent) }\end{array}$ & \\
\hline 1.1 & & 0 & $<3$ & 1578 & "Contaminant" & URI & Ureteric reflux \\
\hline 2.9 & & 3 & 0 & 1568 & Neg & Poor epilepsy control & Cerebral palsy \\
\hline 6.1 & & $<1$ & 0 & 1408 & Neg & PUO & \\
\hline 7.0 & & $4-5$ & 4 & 1286 & Coag neg staph & Trauma case, routine sample & \\
\hline 14.8 & & 0 & 0 & 1228 & $\mathrm{Neg}$ & Epigastric pain & \\
\hline 0.2 & & 0 & $<3$ & 1212 & "Contaminant" & PUO & Rickets \\
\hline \multirow[t]{2}{*}{0.01} & Sm1 & 0 & 0 & 1032 & Neg & Postoperative diaphragmatic & \\
\hline & $\begin{array}{l}\text { Sm } 1+1 \\
\text { day }\end{array}$ & 0 & 0 & 998 & & hernia & \\
\hline 4.4 & & $1-2$ & 0 & 1012 & Neg & Pneumonia & $\begin{array}{l}\text { Acute leukaemia with } \\
\text { neutropenia }\end{array}$ \\
\hline 2.9 & & 0 & $<3$ & 946 & $\begin{array}{l}\text { "Mixed } \\
\text { contaminants" }\end{array}$ & Routine sample & Recurrent UTI \\
\hline 0.2 & & 0 & $<3$ & 832 & "Contaminant" & Routine sample & Anaemia, constipation \\
\hline 3.3 & & 0 & 0 & 802 & Neg & Balanitis & Incontinence \\
\hline 6.1 & & $<1$ & 0 & 782 & $\mathrm{Neg}$ & PUO; pneumonia & \\
\hline 9.1 & & $2-3$ & 4 & 766 & $\begin{array}{l}\text { "Mixed } \\
\text { contaminants" }\end{array}$ & Appendicitis & \\
\hline 4.6 & & 0 & 0 & 720 & $\mathrm{Neg}$ & & $\begin{array}{l}\text { Neuropathic bladder, } \\
\text { constipation, caries }\end{array}$ \\
\hline 5.9 & & 0 & 0 & 640 & Neg & PUO & $\begin{array}{l}\text { Acute leukaemia with } \\
\text { neutropenia }\end{array}$ \\
\hline 12.8 & & 0 & 0 & 640 & Neg & Abdominal pain & Pinworm infestation \\
\hline 0.9 & & 0 & 0 & 556 & Neg & & $\begin{array}{l}\text { Postoperative abnormal urethra } \\
\text { and genitalia }\end{array}$ \\
\hline 0.1 & & 0 & 0 & 554 & Neg & $\begin{array}{l}\text { Pneumonia; postoperative } \\
\text { diaphragmatic hernia }\end{array}$ & \\
\hline 8.0 & & 0 & 0 & 476 & Neg & Routine sample & $\begin{array}{l}\text { Newly diagnosed diabetes } \\
\text { mellitus }\end{array}$ \\
\hline 1.4 & & $1-2$ & $<3$ & 430 & $\begin{array}{l}\text { Coliform and coag } \\
\text { neg staph }\end{array}$ & PUO & Fragile X syndrome \\
\hline $0.1-15$ & $\mathrm{n}=18$ & $0-2$ & $<3$ & 0 & All negative & $\begin{array}{l}\text { URI (5), PUO (1), routine } \\
\text { sample ( } 7 \text {, diarrhoea and } \\
\text { vomiting (3), abdominal pain } \\
\text { (1) }\end{array}$ & $\begin{array}{l}\text { Recurrent UTI (4), } \\
\text { Henoch-Schonlein purpura (1), } \\
\text { non-urological disorders }(9)\end{array}$ \\
\hline $0.2-8.5$ & $\mathrm{n}=13$ & 0 & $<5$ & 0 & Neg & & No clinical information \\
\hline $2.1-6.1$ & $\mathrm{n}=5$ & $1-4$ & 0 & 0 & Neg & & No clinical information \\
\hline $0.1-18.4$ & $\mathrm{n}=180$ & 0 & 0 & 0 & $\mathrm{Neg}$ & & Information not sought \\
\hline
\end{tabular}

UT(I), urinary tract (infection); URI, upper respiratory infection; PUO, pyrexia of unknown origin; N/A, not available; WCC, white cell count; org ct, organism count; coag neg staph, coagulase negative staphylococcus; Sm, sample; Neg, negative.

tract process identified to explain the urinary findings (a girl with vaginitis). Of the seven samples in which no IL-8 was detected and records were found, one was from a child with underlying known urinary tract problems being sampled routinely, while the remainder had respiratory infections $(\mathrm{n}=3)$, constipation $(n=2)$, or pyrexia of unknown origin $(n=1)$.

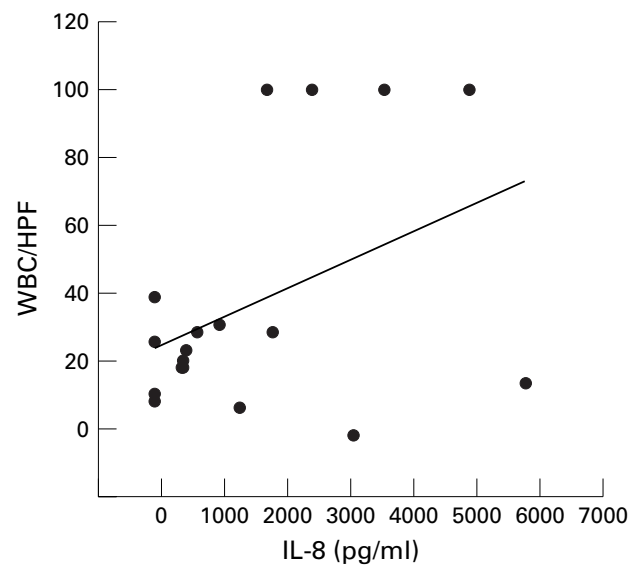

Figure 1 Correlation between IL-8 concentration and white cell number in urine samples from children with UTI (group 1, table 1). WBC/HPF, white blood cells per high powered field.
The mean, median, and range values for the 21 samples fulfilling the criteria for possible UTI were $1003 \mathrm{pg} / \mathrm{ml}, 404 \mathrm{pg} / \mathrm{ml}$, and 0-8334 $\mathrm{pg} / \mathrm{ml}$.

Patients in group 2 were somewhat older than those in group 1, with only two of the 16 for whom age data were available aged less than 2. Data on bacterial species were only available in six of these samples (four coliforms, two coliforms and coagulase negative staphylococcus) as the rest were culture negative.

GROUP 3

Of the remaining 257 samples from 228 patients who were not designated "urinary tract infection" or "possible UTI", there were 24 samples from 23 patients which had detectable IL-8. One of these cases had seven other samples taken, none of which contained IL-8. Clinical data were sought in these 23 cases and found in every case (table 4 ). In addition clinical data were sought for 36 cases where $<5$ white cells $\times 10^{9} / 1$ or $<10^{5}$ bacteria $/ \mathrm{ml}$ were identified in the urine but no IL- 8 was detected (table 4). However, clinical information was only found in 18 of these cases. This low yield was because these records were sought at a later date following archiving of records, which resulted in much material becoming hard to 
locate. Since uncertainty exists about the clinical course of the 18 other cases for which records were not found (table 4, 2nd and 3rd last lines), they were excluded from analysis of the value of IL-8 as a diagnostic test for UTI (see below). Clinical data from the remaining 190 samples (180 patients) were not sought (table 4, last line).

Of the 23 children in this group, in whose urine IL-8 was found, seven were children with some form of chronic urinary tract abnormality or recurrent urinary tract disease, but even among these several had other identified pathologies (such as respiratory tract infection) or manifestly did not have current UTI since there were neither white cells not bacteria in their urine. The remaining cases with IL- 8 in their urine had a wide variety of abnormalities affecting various organ systems (see table 4 ). In none of these children was the clinical diagnosis of UTI made or treatment intended for UTI started.

Among the 18 children with low numbers of white cells or bacteria in their urine, but no IL-8 detected, there were four with antecedent histories of recurrent UTI. However, none of them had UTI diagnosed at or around the time that these urine samples were taken.

The mean, median, and range values for the 257 samples from this group, judged not to have UTI were $117 \mathrm{pg} / \mathrm{ml}, 0 \mathrm{pg} / \mathrm{ml}$, and 0-3960 $\mathrm{pg} / \mathrm{ml}$.

POTENTIAL VALUE OF URINE IL-8 AS A DIAGNOSTIC MARKER

The observations summarised above suggest that IL- 8 in urine may be a relatively sensitive but rather poorly specific test for UTI in children.

However, the study exemplifies the difficulty of assessing this formally because of the large number of children in whom the "gold standard" tests (urinary leucocytes and bacterial culture) produce equivocal results.

A review of the clinical data from children falling into the microbiological definitions used in the study for UTI (group 1) and not UTI (group 3), suggests that these definitions worked well and these groups are indeed true cases of UTI and true cases of "not UTI" respectively.

Using these two groups, the sensitivity of urine IL-8 as a marker, using our lower limit of detection as a cut off value $(200 \mathrm{pg} / \mathrm{ml})$ was $93 \%$. In other words, the test correctly identified $93 \%(13 / 14)$ of those with UTI, and failed to detect the disease in $7 \%$ of cases $(1 / 14)$. However, these figures only apply when repeat samples taken on the same children are included in the analysis. If analysis is restricted to samples diagnostic for UTI by the presence of $\geqslant 5$ white cells $\times 10^{9} / 1$ and positive culture (table 1 ), the sensitivity drops to $86 \%(12 / 14)$.

The specificity of the test was $90 \%$. It correctly identified $90 \%(198 / 228)$ of those who did not have UTI but was positive in $10 \%$ $(23 / 228)$ of cases where UTI was absent.

The receiver-operator characteristic curve (ROC, fig 2), constructed by plotting the sensitivity versus the specificity for different cut

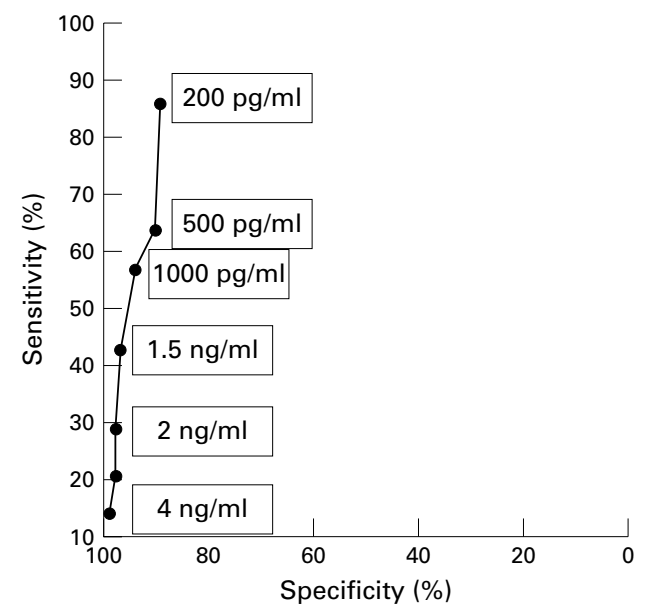

Figure 2 ROC curve showing sensitivity and specificity of urine IL-8 for diagnosing UTI at different cut off values of IL-8.

off concentrations of I-L8 in urine, shows that using higher cut off concentrations of urinary IL-8 concentration than $200 \mathrm{pg} / \mathrm{ml}$ rapidly reduces the sensitivity of the test for diagnosing UTI.

\section{Discussion}

Infections of the urinary tract activate local and systemic cytokine responses. Release of cytokines from the site of infection precedes the onset of fever, acute phase responses, and neutrophil responses. ${ }^{13}$ IL- 8 is an important early mediator of inflammation and a chemoattractant for neutrophils. Previous studies have shown that IL- 8 is present in urine specimens from children with UTI and that urine IL-8 concentrations correlate with the numbers of neutrophils. ${ }^{911}$ However, IL-8 is only one of many known chemotactic factors for neutrophils, and others are also likely to operate in the pathogenesis of UTI.

In the present study, we identified 15 children fulfilling a fairly strict microbiological definition for UTI. Examination of the records of all of these cases reconfirmed that the diagnosis was correct. The group included a higher number of children with confirmed urinary tract abnormalities than might be expected from a typical sample of children with UTI. We explain this on the basis that the study was done in a hospital which acts as a tertiary centre for paediatric medical and surgical referrals.

Fourteen of these 15 patients and 13 of the 17 urine samples obtained from them, showed $>200 \mathrm{pg} / \mathrm{ml}$ IL-8. This suggests the cytokine is a sensitive but imperfect marker for UTI. There are several possible reasons why IL-8 was not detected in all these cases.

Firstly, since IL- 8 is a strong chemotactic stimulus for neutrophils, it may precede them in the urine and disappear earlier than white cells or bacteria in the pathogenesis of UTI in some cases. This could explain the findings in the case where IL-8 was detected in a first sample, free of white cells and bacteria, but was then not found in a second taken a day later in which white cells and bacteria were present.

Secondly, the way in which samples are handled after being obtained may influence 
whether IL-8 is detectable by immunoassay done subsequently. The temperature and length of frozen storage may influence this. Perhaps more importantly, the handling of the sample from the time it leaves the child to when it arrives in the laboratory may be critical. We re-examined the records of the child whose UTI would not have been detected by looking for IL- 8 and found that at least 20 hours elapsed between the time the diagnostic sample was obtained and when it was booked in at the laboratory. As we do not have comparable data on other samples, the significance of this finding is uncertain, but it raises the possibility that sample handling could be critical if IL- 8 were to be used as a diagnostic marker in clinical practice.

Thirdly, the sensitivity of the immunoassay we used is not optimal. It is possible that some of the samples in which we failed to detect IL-8 contained the cytokine at concentrations below $200 \mathrm{pg} / \mathrm{ml}$. Our assay was developed in house using antisera which had been stored and in use for some time. Commercial kit immunoassays are now available which have detection limits at least 10 times lower than ours. Such improved performance might improve the sensitivity of the assay (although using lower detection limits might also impact adversely on the specificity).

We identified more than twice as many children with detectable IL-8 in their urine ( $n=34$ ) whose samples did not fulfil the study definition of UTI, than children whose samples did $(n=14)$. Of the 34 , only two were judged to have had and were treated for UTI by the clinicians looking after them. Clearly, on the basis of this evidence, urine IL- 8 would not be a good screening tool for UTI. Many of these cases had other demonstrable reasons for inflammation within or adjacent to the urinary tract, such as recent urinary tract surgery or manipulation, vaginitis, or balanitis. Others had known inflammatory processes at remote sites, such as pneumonia, acute pancreatitis, appendicitis, and traumatic injuries. This suggests that the cytokine may be cleared from the bloodstream by the kidneys, so becomes detectable in urine following inflammation elsewhere.

Detectable serum IL-8 has recently been reported in patients with acute pancreatitis, ${ }^{14-17}$ but the presence of IL-8 in urine has not previously been reported in pancreatitis. Rodriguez et al investigated patients with nosocomial pneumonia showing bronchial secretion of IL- 8 , but none in the urine. ${ }^{18}$ The presence of IL-8 in bronchoalveolar fluid from patients with pneumonia has also been reported elsewhere. ${ }^{19}$ IL-8 has not previously been described in the urine of patients with appendicitis.

The shape of the ROC curve (fig 2) reconfirms the suboptimal lower limit of detection of our assay. It is likely that a more sensitive assay system would complete the more typical shape seen in these curves, with a sharp drop in specificity as sensitivity approaches $100 \%$. However, further studies using more sensitive techniques and examining more strictly controlled sample handling procedures would be necessary to reconfirm this speculation.

Immunoassays such as the one used in this study take a few hours to perform, which compares favourably with the 24 to 48 hours necessary for bacterial culture. On the other hand, they are significantly less quick and easy to perform than urinary microscopy for white cells, particularly when considering that it is desirable to batch samples for analysis by immunoassay. Even a large microbiology laboratory would be unlikely to be able to run such tests more than once a day and it would be impractical to provide the test out of office hours. It is hard to compare relative unit costs of these different tests as current cytokine assay kits are not manufactured for clinical diagnostic use.

We conclude from our study that measurement of IL-8 in urine has only limited potential value as an adjunct to urine microscopy and culture for clinicians wishing to diagnose UTI in children. In some cases, where there is a high index of suspicion, the presence of IL-8 might help with the decision to treat as UTI, if microscopy results are equivocal and culture results not yet available. However, the fact that inflammatory and infective disorders of other body systems apparently result in release of detectable IL- 8 into urine, as well as other practical issues such as the potential need for careful sample handling, laboratory time for analysis, and cost, limit the value of this investigation relative to conventional techniques.

This study was supported by grant funding from the Children's Appeal, Sheffield. The authors thank Dr Craig Smith who assisted with the collection and storage of the samples.

1 Vernon S, Foo CK, Coulthard MG. How general practitioners manage children with urinary tract infection: an audit in the former Northern Region. Br f Gen Pract 1997;47:297 300 .

2 Schmouder RL, Strieter RM, Wiggins RC, et al. In vitro and in vivo interleukin-8 production in human renal cortical in vivo interleukin-8 production in

3 Nakanishi I, Moutabarrik A, Okada N, et al. Interleukin-8 in chronic renal failure and dialysis patients. Nephrol Dial Transplant 1994;9:1435-42.

4 Jacobson SH, Hylander B, Wretlind B, Brauner A. Interleukin-6 and interleukin- 8 in serum and urine in patients with acute pyelonephritis in relation to bacterialvirulence-associated traits and renal function. Nephron 1994;67:172-9.

5 Fitzpatrick MM, Shah V, Trompeter RS, et al. Interleukin-8 and polymorphoneutrophil leucocyte activation in hemolytic uremic syndrome of childhood. Kidney Int 1992;42: 951-6.

6 Smith SD, Wheeler MA, Lorber MI, Weiss RM. Temporal changes of cytokines and nitric oxide products in urine from renal transplant patients. Kidney Int 2000;58:829-37.

7 Boratynska M. Monitoring of interleukin-8 in urine and in serum of patients after kidney transplantation. [Polish]. serum of patients after kidney trans
Przeglad Lekarski 1998;55:576-80.

8 Wada T, Yokoyama H, Tomosugi $\mathrm{N}$, et al. Detection of urinary interleukin-8 in glomerular diseases. Kidney Int 1994; nary interleukin 455 - 60 .

9 Ko YC, Mukaida N, Ishiyama S, et al. Elevated interleukin-8 levels in the urine of patients with urinary tract infections. Infect Immun 1993;61:1307-14

10 Roilides E, Papachristou F, Gioulekas E, et al. Increased urine interleukin- 6 concentrations correlate with pyelonephritic changes on $99 \mathrm{mTc}$-dimercaptosuccinic acid scans in neonates with urinary tract infections. F Infect Dis 1999; 180:904-7.

11 Benson M, Jodal U, Agace W, et al. Interleukin (IL)-6 and IL-8 in children with febrile urinary tract infection and asymptomatic bacteriuria. F Infect Dis 1996;174:1080-4.

12 Abu-Harb M, Bell F, Finn A, et al. IL-8 and neutrophil elastase levels in the respiratory tract of infants with RSV bronchiolitis. Eur Respir $\mathcal{F}$ 1999;14:139-43.

13 Agace WW, Hedges SR, Ceska M, Svanborg C. Interleukin-8 and the neutrophil response to mucosal gram-negative infection. $\mathcal{F}$ Clin Invest 1993;92:780-5. 
14 Hynninen M, Valtonen M, Markkanen H, et al. Intramucosal $\mathrm{pH}$ and endotoxin and cytokine release in severe ;13:79-82.

15 Simovic MO, Bonham MJ, Abu-Zidan FM, Windsor JA Anti-inflammatory cytokine response and clinical outcome in acute pancreatitis. Crit Care Med 1999;27:2662-5.

16 Berney T, Gasche Y, Robert J, et al. Serum profiles of interleukin-6, interleukin-8, and interleukin-10 in patients with severe and mild acute pancreatitis. Pancreas 1999;18: $371-7$
17 Chen CC, Wang SS, Lee FY, et al. Proinflammatory cytokines in early assessment of the prognosis of acute pancreatitis. Am f Gastroenterol 1999;94:213-18.

18 Rodriguez JL, Miller CG, DeForge LE, et al. Local production of interleukin-8 is associated with nosocomial pneumonia. F Trauma 1992;33:74-81.

9 Buhling F, Tholert G, Kaiser D, et al. Increased release of transforming growth factor (TGF)-beta1, TGF-beta2, and chemoattractant mediators in pneumonia. $\mathcal{F}$ Interferon Cytokine Res 1999;19:271-8.

\section{A paediatric axiom}

How is a general practitioner (or a paediatrician, for that matter) to know that a child has a relatively rare disease such as cancer? The answer, perhaps, lies in a paediatric commonplace, an axiom of paediatric practice: listen carefully to the parents - they know their own child and are probably right. (Don't all medical students have that branded on their brain stems on their first day in paediatrics?) Axioms, of course, don't have to be proved; they are agreed starting points from which everything else follows. Paediatrics has but one axiom of axioms: the best interests of the child come before everything else. That's the ace of trumps in the axiom pack. As a subsidiary axiom though, this one (the one about parents) doesn't seem a bad card to hold in your hand. It's an axiom to remember. (We'll forget child abuse for now; that's covered in the panaxiom.) Perhaps a Radio 2-type jingle would help to preserve and spread the meme:

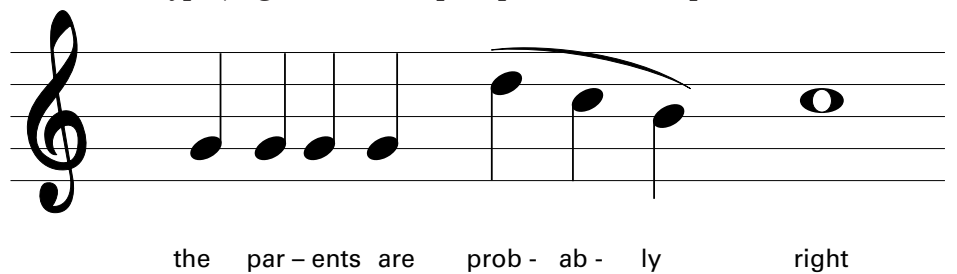

Now you shouldn't be able to stop singing that to yourself for the rest of the day.

In Leicester (Mary Dixon-Woods and colleagues. Lancet 2001;357:670-4) semistructured interviews were conducted with parents of 20 children, some one to 36 months after the diagnosis of cancer (leukaemia (9), brain tumour (2), other solid tumour (9)) in their child. Disputes with doctors had occurred in 10 cases, almost invariably because of delays in diagnosis when the parents "knew there was something wrong". Three of these 10 children had acute lymphoblastic leukaemia and the diagnosis was made on a blood test after a 3 or 4 week period of "wait and see". (Many parents accepted that such delay was reasonable when the symptoms were non-specific.) Seven of the 10 had solid tumours diagnosed between 2.5 and 8 months after the onset of symptoms. What upset parents was failure to investigate persisting symptoms, failure to investigate alarming symptoms such as fits, incoordination, sudden onset paralytic squint, or haematuria, and failure to give enough credence to their feeling that something about their child was "not right". Diagnostic delays occurred both in general practice and in secondary paediatrics. Sometimes the wait to be seen in a paediatric clinic seemed unduly long. Some older children hid their symptoms or resisted being taken to a doctor.

This type of research, being purely qualitative, tells us nothing about the positive predictive value of "not-right-ness". But parents are specialists on the subject of their own child and, although their recollections could have been influenced by various factors such as fear, anger, self blame, or the human need to say "I told you so", the facts as related by these parents were usually confirmed by the medical records. Parents aren't always right, of course, and reassurance (though not empty, ill considered reassurance) is important but, at the very least, believing in the axiom makes us nicer people.

In primary or secondary practice the probability of a child having cancer is usually low, but parental concern is a factor which must weigh heavily in any child care equation. Humility and an ear to listen with; how often has any one of us been short of either or both? Remember, da da-da da da-da-de da. Go on, sing along with Archie. 